\title{
GÎYA DI DÎWANA ŞÊX EBDURRAHMANÊ AQTEPÎ DA
}

\author{
Osman Aslanoğlu ${ }^{1}$
}

\begin{abstract}
KURTE
Şêx Ebdurrehmanê Aqtepî (1842-1910) li navçeya Çinarê ya Amedê hatiye dinyayê. Sêxxekî Neqşîbendî-Xalidî bû. Lê di heman demê de muderrîs, lêkolîner û helbestvan bû. Di gelek qadên cuda da berhemên pir girîng nivîsandine. Piranîya berhemên wî bi Erebî ne. Lê du berhemên xwe yên Kurdî/Kurmancî hene. Yek Rewdunneîm e û ya din jî dîwana wî ye. Navê dîwana wî Dîwana Rûhî ye û bi awayekî klasîk hatiye nivîsandin. Aqtepî di dîwana xwe de tevî mijarên cur bi cur bi qasî ku me fehm kir bi giranî li ser evîna îlahî sekinîye. Di helbestên xwe yên tesewwufî́-evînî de ji mezmûnan pir îstîfade kiriye. Ev mezmûn bi piranî ji qadên wek ajal, gîya, kesayet û endamên xweşikîya yarê ne. Em ê di vê xebatê de li ser beşa gîyayan bisekinin. Di beşa gîyayan da dar, meywe û kulîlk hene. Ev mezmûn di helbesta klasîk da bi piranî ji bo xweşikîya yarê tên bikaranîn. Aqtepî jî bi heman awayî cih daye șibandinên bi vî rengî. Aqtepî dora 14 heb nîșaneyên gîyayî bi kar anîne. Hinek ji van bi alîyekî tenê, hinek jî bi çend alîyan hatine behskirin. Em ê ji bo her mezmûnekê, eger çend wateyên cuda hebin behsa wan bikin û mînakên wek hev ên derbarê wê wateyê li bin bidin. Bi vî awayî nêrîna edebî ya Aqtepî ya li ser gîyayan baştir dê were dîtin û fehmkirin.
\end{abstract}

Peyvên Sereke: Aqtepî, Mazmûn, Dîwan, Gîya, Kulîlk, Dar, Dîwana Rûhî

\section{Şeyh Abdurrahman Aqtepî’nin Divanında Nebat}

\section{ÖZ}

Şeyh Abdurrahman Aktepî Diyarbakır'ın Çınar ilçesinde dünyaya geldi. Nakşibendî-Halidî şeyhi idi. Aynı zamanda müderris, araştırmacı ve şairdi. Çok farklı alanlarda önemli eserler yazmıştır. Eserlerinin çoğu Arapça'dır. Ancak iki Kürtçe/Kurmancî eseri vardır. Biri Ravdunneîm, diğeri ise divanıdır. Divanının adı Divan-1 Ruhî olup klasik tarzda yazılmıştır. Aktepî divanında farklı konularla beraber anladığımız kadarıyla ağılıkla ilahi aşk üzerinde durmuştur. Tasavvufî-aşk şiirlerinde pek çok mazmun kullanmıştır. Bu mazmunlar daha çok hayvan, bitki, kişilik ve sevgilinin güzellik unsurlarıdır. Bu çalışmamızda bitkiler grubu üzerinde duracağız. Bitkiler grubunda ağaçlar, meyveler ve çiçekler vardır. Bu mazmunlar klasik şiirde çoğunlukla sevgilinin güzelliği için kullanılır. Aktepî de aynı şekilde bu türden benzetmelere yer vermiştir. Aktepî 14 kadar bitkisel mazmun kullanmıştır. Bazıları bir açıdan, bazıları ise bir kaç açıdan işlenmiştir. Biz her bir mazmun için kaç tane farklı anlam varsa onlara yer vereceğiz. $\mathrm{O}$ anlamla ilgili benzer örnekler ise altında verilecektir. Bu şekilde Aktepî'nin bitkiler hakkındaki edebî yaklaşımı daha iyi görülecek ve anlaşılacaktır.

Anahtar Sözcükler: Aqtepi, İmaj, Divan, Nebat, Ağaç, Ruhi Divanı

${ }^{1}$ Dr. Öğr. Üyesi, Dicle Üniversitesi, Edebiyat Fakültesi, Kürt Dili ve Edebiyatı Bölümü, aslanogluosman@gmail.com. ORCID: https://orcid.org/0000-0001-6534-3125 


\title{
Plants in the Divan of Sheikh Abd-el-Rahman Aktepi
}

\begin{abstract}
Sheikh Abdurrahman Aktepi (1842-1910) was born in the Çinar district of Diyarbakır. He was a Naqshbandi-Khalidi sheikh. He was also a lecturer, researcher and poet. He has written crucial works in many different fields. Most of his works are in Arabic. However, he has two Kurdish/Kurmanji works. One of them is Ravdu'n Naim and other one is the Divan. The name of the Divan is "Divan of Ruhi" and it has been written in classical style. Along with different subjects, as we understand he has focused more on divine love in his Divan. He has utilized a lot from images in his poems themed mysticism and love. These symbols are mostly animals, plants, personality and beauty elements. In this study, we are going to focus on the group of plants. There are trees, fruits and flowers in this group. These images are mostly used for lover and for its beauty elements in classical poetry. Aktepi has also likewise given place to such metaphors. Aktepi has given place 14 images in this field. Some of them have been studied from only one aspect, some of them from several aspects. We will talk about all the different meanings they have that are loaded on them and give examples of same types one under the other. In this way, Aktepi's literary view of plants will be seen and understood better.
\end{abstract}

Keywords: Aktepi, Images, Divan, Plant, Flower, Tree, Divan of Ruhi

\section{Destpêk}

Remz di jîyana mirovan de ji serdemên ewil da hebûne. Mirovan ji bona ku xwe ji kesên din cudatir bikin û ji ber hin sedemên din nîşaneyên cuda bikar anîne. Ev nîşane bi wateyên xwe wek ala û 'elem, bûne elameta wan kesan û milletan. Piranîya remzan ji wêneyên heywanan, ji alavan û dar û beran dihatin hilbijartin. Mirovan gelek wate li van tiştan bar dikirin û ji bo hin peyaman ev remz bikar dianîn. Di dîroka gelek neteweyan da ev nîşane bi madenan wek heykel hatine çêkirin an li ser çîya, zinar, kevir, text û kaxezên cur bi cur hatine neqişandin (Erdem, 1989: 352). Bi vî awayî mirovan bi van şeklan jîyana xwe xemilandiye. Piştî ku di jîyana rojane ya civakî da li ajalan, alavan, dar û kulîlkan û hetta şexsîyetan gelek wate hatin barkirin, mirovan ev remz di berhemên xwe da, di wêjeyê de û bi taybet di helbestan da bikar anîn.

Remzên ku di wêjeyê da hatine bikaranîn ra mezmûn tê gotin. Her neteweyekê bi bandora çanda xwe, bi fikra xwe, wate û şîroveyên cuda li van mezmûnan kirin. Helbestvanan ji bo gotinên bi bandor û kurt lêbelê kûr, ji van mezmûnan îstîfade kir. Gelek wate û sifetên cuda bi van mezmûnan îfade kirin. Di wêjeya hin netewan an herêman da bikaranîna sembolan di berhemên tesewwûfî da dest pê kiriye. Ji ber ku mutesewwûf ji ber şertên hakim û heyî, nikare hestên hundirê xwe eşkere bike. Ji ber vê serî li bikaranîna mezmûnan dide (Pûrnamdarîyan û Şakirî, 1391: 26). Helbestvanan jî gelek tişt, bi van mezmûnan şibandin hev. Bi vî awayî hunera şibandinê ket nav mijara helbestên sembolîk. Wek mînak: Ji bo cesaretê şêr, mezmûnek e. Lê helbestvan dema behsa yekî wêrek dike, di 
navbera şêr û wî da şibandinê jî dike. Bi vî awayî mijara mezmûnan bi piranî bi hunera şibandinê va giradayî ye.

Ji van mezmûnan em ê di vê xebatê da li ser gîyayan rawestin. Bi têkilîya helbestvanan û çanda hezar salî di bikaranîna mezmûnan da êdî kevneşopîyek çêbûye û ji bo wan wateyên sereke rûniştine. Ev wate bi piranî ji bo yarê û endamên xweşikîya yarê ku armanca wan evîna îlahî ye û wateyên tesewwufî ne, hatine bikaranîn. Wek neteweyên din ên rojhilatî Kurdan jî di berhemên xwe yên wêjeyî da ji van mezmûnên gîyayî îstîfade kirine. Ji helbestvanên dûrdem ên Kurd Baba Tahîrê Uryan û Elîyê Herîrî bigirin heta Melayê Cizîrî, Ehmedê Xanî, Feqîyê Teyran û helbestvanên dema me gelek helbestvanan cih daye Mezmûnên gîyayî. Şêx Ebdurrehmanê Aqtepî (1842-1910) jî bi bandora helbestvanên berê xwe li ser kevneşopîya berîya xwe çûye û gelek mezmûnên ji gîyayan bikar anîne.

Di wêjeyê de bi taybetî di helbestê de mezmûn ji bo beyana gelek wateyên kûr tên bikaranîn. Nîşane carinan bi tevgerên xwe, carinan bi rewş, şekl, reng, deng û bîhna xwe xwedîyê hin wateyan in. Wek mînak: şêr, him bi şekl û dîmena xwe, him jî bi zexmbûna xwe cesaret û wêrekîyê temsîl dike. Ji ber vê wek remza cesaretê û hêzê di wêjeyê de cih girtiye (Canbazî, 1394: 60; Nîhanî, 1394: 50). Lêv, yaqût û şerab bi rengê xwe yên sor hatine behskirin. Qedeha şerabê ji alîyê rewş, şekl û reng va tê nirxandin; bi rewşa xwe wek camekê dikare bişkê, bi şeklê xwe wek dil e, bi rengê xwe wek xwîn e. Bi van taybetîyan qedeh û dil bi hev ra têkildar dibin (Tarlan, 1998: 27, 42). Bi heman awayî di helbestan da gîya yanî dar û ber û kulîlk bi gelek alîyan hatine bikaranîn. Bi taybet di helbesta klasîk da mezmûnên gîyayan gelek bikar hatine. Bax, baxçe, keskahî, hêşînahî, dar û ber û kulîlk bi dîmenên xwe yên xweşik bala mirovan dikşînin. Bi zimanê xwe yê halî û rewşî ji mirovan ra tiştinan dibêjin. Razên hundirê xwe vedibêjin. Helbestvan razên veşartî yên wan, bi nêrîna xwe derdixin holê (Rengçî, 1372: $5)$.

Di helbesta klasîk a Farsî, Erebî û Tirkî da ev mezmûn çawa hatibin bikaranîn, di helbesta klasîk a Kurdî da jî hema hema bi eynî taybetîyan hatine xebitandin. Hin cudahîyên girêdayê çanda wan helbet hene. Bi taybet di helbestên evînî de û tesewwufî da remz û wateyên wan gelek rûniştine û helbestvan bi piranî şibandinên wek hev dikin. Tenê asta hunera bikaranîna van ji hev cuda dibe.

Aqtepî jî wek helbestvanên klasîk ên berîya xwe mezmûnên gîyayî bikar anîne. Ev bikaranîn carinan wek helbestên klasîk ji bo evîna îlahî di nav helbestên eşkere dînî û tesewwûfî da pêk hatiye. Rêjeya bikaranîna gîyayan a di van da herî hindik e. Carinan di helbestên evînî da dema ku li ser xweşikîya yarê tê sekinandin û nişsaneyên gîyayî tên bikaranîn. Ev cure helbest zêde ne. Li ser xweşikîya yarê ji xwezayê zêdetir şibandin tên kirin. Lê divê were zanîn ku ji ber kesayeta Aqtepî ya dînî û tesewwûfî di helbestên wiha evînî da jî mebest ji yarê Xweda ye. Hinek cure helbest jî hene ku Aqtepî herî zêde di wan da behsa 
xwezayê dike. Helbestên wiha hindik in, lê tê da tewsîfa xwezayê pir hatiye kirin û navê gîyayan pir bikar hatine. Wek ku Aqtepî mîna Feqîyê Teyran dîmenên xwezayê û biharê pêşkeş dike. Aqtepî bi taybet di helbesta 11'an a bi destpêka "kesk $\hat{u}$ sor $\hat{u}$ şîn $\hat{u}$ zer", helbesta 15an a bi destpêka "lebgul $\hat{u}$ gerdangul" û helbesta 27'an a bi destpêka "purpizêk min girt yed" behsa xwezayê bi awayekî berfireh dike û di hemûyan da li ser têkilîya bi xweşikîya yarê ve disekine.

Aqtepî di helbestên xwe de bi piranî navê kulîlkan bikar anîye. Ji kulîlkan jî herî zêde navê gulê bikar anîye. Jixwe ev rewş di helbesta klasîk da jî bi piranî bi heman şeklî ye. Helbestvanan zêde behsa navê gulê kiriye. Aqtepî ji bilî gulê, nesrîn, lale, nêrgîz, sosin û reyhan jî bikar anîne. Xencî kulîlkan darên serwîyê, 'er'erê û tirî jî kiriye mezmûn. Wekî din gîyayê qamişê şêkir (nebat) û pîvaz jî hatiye bikaranîn. Em ê yek bi yek li ser van û wateyên ku lê hatine barkirin bisekinin. Ji bo malikên mînakî me dîwana ku ji Weşanên Belkîyế ${ }^{2}$ derketiye bi kar anî û di dawîya mînakan da bi hesaba rêza helbestan a di pirtûkê da me jimara helbestê û jimara malik an ristan li ba hev da.

\section{Kulîlk, Çîçek}

Kulîlk, beşa rengîn û bibîhn û tovdar a gîyayan e ku bi wan tovan zêde dibin. Ji bergên sehenî, bergên tacî û tovan pêk tê. Di tevahîya dîrokê da di jîyana takekesî û civakî ya mirovan da xwedîyê cihekî girîng bûye. Ev navê giştî jî wek cureyên wê di helbesta klasîk da zêde bikar nayê. Bi piranî ji bo teswîra bihar û baxan bi awayekî giştî tê gotin. Dema ku bax, di şibandinê da ji bo tiştekî tê bikaranîn, kulîlk ji bo kes an tiştên di nav wir de tê gotin. Wek mînak her tiştê ku cihekî dixemilîne bi kulîlkan tê şibandin. Ger helbestvanî bi baxekî ve were şibandin, helbestên wî wek kulîlk tên hesibandin (Rengçî, 1372: 11; Malmîr, 1396: 37; Tarlan, 1998: 123). Lê cureyên kulîlkan zêdetir bi endamên xweşikîya yarê tên şibandin. Her kulîlkek endameke bedenê temsîl dike. Wek ku gul, rû ye; nêrgîz çav e; lale dil e, Yasemîn spîtîya bedenê yarê ye. Di helbestan da bi piranî bi bêjeyên ezhar, şukûfe, kulîlk û gul derbas dibe.

\section{a- Rengînî}

Wek navê giştî kulîlk an çiçek xemla hemû bax û baxçe û mêrgan e. Dema behsa xweşikîya van deran an cihekî tê kirin, behsa rengînîya kulîlkan tê kirin. Ji ber ku xemla xweş kulîlkên rengîn in. Aqtepî bêjeya tirkî "çîçek"ê di şûna "kulîlk"a kurdî bi kar tîne û wexta ku biharê pênase û şîrove dike li ser rengên wan, vebûna wan li nav baxçeyên çivîkan û li mêrgan disekine. Aqtepî ji bo rengînîya wan jî mînaka netewên bi rengên cuda dike. Yek ji van Rom e û a din

\footnotetext{
${ }^{2}$ Aqtepî, Şêx Evdirrehman, (2013). Şêx Evdirrehmanê Aqtepî Dîwana Rûhî, Amadekar: Rênas Jiyan, Diyarbakır: Weşanên Belkî.
} 
Habeş e. Yanî çawa ku rengên van milettan spî û reş e, kulîlk jî dema biharê li nav çîmên reng rengî ne:

Wek di nîsan rengereng, çîçek vebin der murxîzar

Muxtelit bûn têk di çîmen leşkerê Rom û Hebeş 11/2

\section{b- Xweşikî}

Kulîlk bi reng û bîhna xwe ya xweş nîşanên xeml û xweşikîyê ne. Her cihê ku dikevinê xweş dikin. Eger evîndar, ji hezkirîya xwe dûr be, xweşikîya kulîlkan jî li ber çavê wî wenda dibe. Dilê wî nare wan kulîlkên xweşik jî:

Purpizêk min girte yed lakin ji hukmê firqetê

Purpizêk $\hat{u}$ çîçek $\hat{u}$ sorgul di bîra min ne tê 27/1

\section{Gul, werd:}

Gul, ji malbata gulîyan (Rosaceae) e ku gelek cureyên wê hene, bîhnxweş e û bi istirî ye. Ji cinsê gîyayên wek daran e. Di meha Gulan û Pûşperê da vedibin. Kulîlkên wê dîmenxweş in. Ji aliyê şeklê pelan va hinek cureyên wê sade, hinek nîvqatqatî û hinek jî qatqatî ne (Devrim, 1999: III, 1266; Zavotçu, 2012: 34). Jê ji gelek alîyan va tê îstîfadekirin. Jê rûnê gulan, ava gulan, bîhn û şîranîyên gulan tên bidestxistin.

Di wêjeyê da û bi taybet di helbestan de kulîlka ku herî zêde tê behskirin gul e. Herî zêde bi navê gul û werd derbas dibe. Wek mezin û fermandarê kulîlkan jî tê qebûlkirin. Di wêjeyê de bi piranî bi rengê xwe û carinan jî bi şeklê xwe cih digre. Gul ji bo yarê wek nîşane û mezmûnek hatiye qebûlkirin. Yanî dema ku gul tê gotin, mebest jê yar e. Xencî vê wek kulîlkên din ji alîyê şeklî û rengî va carinan bi endamên yarê (rû û gup) jî tê şibandin. Lê kulîlkên din bi piranî ji bo endameke bedenî ya yarê tên bikaranîn. Gul herî zêde ji biharê hez dike û payîz û bayê payîzê dujminê wê ye. Ji ber ku payîz mirina gulê ye. Ji ber têkilîya bihar û gulê, ji bo navê biharê "demsala gulan" tê gotin. Ev jî ji gîrîngî û para gulê ya di biharê da tê (Aslanoğlu, 2018: 452; Pala, 2009: 171; Zavotçu, 2012: 2012: 34; Yildırım, Ali, 2012: 2703). Gul, pir temenkurt in. Ji ber ku dema tên qutkirin demeke kin şunda hema diçilmisin û dimirin. Bi vî alîyê xwe nîşaneya temenê kin e (Aktaş, 2002: 25; Hadî, 1394: 52; Enverî, Ferheng-i Kinâyât-ı Sohen, II, 1359). Bi reng û şeklê xwe yê xweşik gul di ferhengên kînayeyan da wek nîşaneya rûyê xweşik derbas dibe. Ji ber ku rû jî wek gulê sor û zindî ye. Ronahîyê dide dora xwe. Gul bi piranî bi bêjeyên wek roj, heyv, bihar, bax, bostan, gulîstan, gulzar, cinnet û çemen ra derbas dibe. Bayê sibê bîhna gulê ji evîndarê wê bilbil ra dibe. Lê bayê payîzê mirina gulê ye. Gul, xweşîyê temsîl dike, lê bê istirî jî nabe.

Di tesewufê gul, nîşaneya vebûna dilê salîk berva marîfet û îrfana xwedê ye. Wekî din gul, bi dil va tê şibandin. Ji ber ku di dil da gelek wateyên îlahî û manewî hene û ev raz û wateyên îlahî wek gul tên hesibandin. Yanî dil baxçeyê 
gulan e (Artun, 2010: 179). Gula ku hîn tam venebûye wek remza wahdetê tê qebûlkirin. Eger tam vebûbe ew wek kesret tê qebûlkirin. Bi hunera îstîareyê di şûna pêxemberê me Hz. Muhammed da jî tê bikaranîn.

\section{a- Gul û istirî}

Gul her çiqas xweşik be û bala meriv bikşîne jî̀, dema meriv destê xwe davêje gulê istirîyên wê nahêlin ku meriv bi rehetî gulê jê ke. Ev jî nîşaneya zehmetî û zorîyên evîndarîyê temsîl dikin. Ji bo wê istirî û gul tim li ba hev in. Di helbestan da istirî bi piranî bi bêjeya "xar"ê derbas dibe. Yanî wek jîyanê bê zehmetî tiştek bi dest nakeve. Evîndar dixwaze gulê bîhn ke, lê nikare zû zû bigêje gulê. Ji ber ku anstengî û reqîbên ku wek istirîyan li hember wî ne, wî aciz dikin. Dilê evîndar ji ber dûrbûna ji gulê, tim derd û mîhnetan dikşîne. Ev derd û zehmetî, dibin xar û di dilê evîndêr ra darin. Li vir xar wek şûr û tîran e ku li dilê evîndêr dikeve:

\section{Dil tijî xarê muxeylane ji hicra sorgulan}

Dê çisan werdê gulan bîn bikim di gel vê mihnetê 27/6

Di helbestên klasîk da li ser afetê pir tê sekinîn. Yar û endamên xweşikîyê li ser evîndar wek afet in. Hemû bela, xwîn rijandin, fîtne û zilm ji wan tên. Aqtepî di helbestekê da her tiştê yarê dişibîne gulê. Bela û zehmetîyên ku ji yarê tên jî wek gul dihesibîne. Yanî gul bi istirîyên xwe gul e; yar bi hîcrana xwe yar e:

Afetê 'eşqa te ser min cumle gul tên gulşenê

Meqseda aşiq çi gul bit seng e gul hem xar e gul 14/12

\section{b- Gul û xunçe}

Xonçe, halê vebûyî yê gulê ye. Carinan di şûna gulê da xonçe tê gotin. Carinan bi hev ra jî tên. Carinan bi şeklê xwe yê girtî û giloverik ji bo dil û qedeha şerabê, carinan bi rengê xwe wek gulê ji bo şerab û êgir û carinan ji bo kesê mest tê gotin. Bi biçûkbûna xwe ciwanîya yarê nîşan dide. Dîsa bi biçûkîya xwe ji bo devê biçûk ê yarê tê gotin ku dîsa mebest jê lêvên sor ên wek gulên biçûk e (Giramî, 1395: 244; Tarlan, 1998: 1985: 68; Çavuşoğlu, 1981: 9, 78):

Xonçe û gul bi hunera tenasubê pir caran bi hev ra tê. Aqtepî di dîwana xwe da li du deran bêjeya xonçeyê bikar tîne. Di yekê da xonçe, bi gulê ra tê. Di wê malikê da Aqtepî xwe wek bilbil dihesibîne. Istirîyên gul û xonçeyê wek tîr li dilê bilbilê evîndar dikevin. Bilbil bi êşa dûrketina ji xonçeyê êş û cefayê dikşîne:

Xedenga firqetê da dil, dinalim şubhetê bilbil

Ji hicra xunçeya sorgul, dikêşim cewr û zîbaê 26/8 
Çawa ku gul him dikeve cihê yarê, him dikeve cihê endamên yarê, xunçe jî ji bo endamên yarê bi taybet ji bo dev û rûyê yarê tê bikaranîn. Helbestvên di malikên jêr da xunçe û dêm bi hev ra anîne. Sibê û êvarî zikra aşiqan yara gulrû ye û wek xunçeyê nûgîya ye, ciwanik e. Li vir bi bêjeya xunçeyê bi taybet biçûkbûn te qesdkirin. Sorbûna rûyê yarê jî nîşana ciwanîyê ye. Ji ber ku her ku sal derbas dibin rengê rûyê ciwanîyê ku sor e û spî ye, berve pîrbûnê û zerbûnê dare:

Zend $\hat{u}$ baz $\hat{u}$ gul bizane kefgul $\hat{u}$ esbe'gul e

Xunçedêm lew aşiqan subh û mesa ezkar e gul 14/8

Taybetîyên yara xweşik di malikeke din da tên rêzkirin. Gul û kulîlkên di tebîetê da û sirûştê da wek Leyla, Şêrîn û Zuleyxa ne. Wek yara xweşik bi nazdarî li her derê digerin. Çavên wan şîrîn in, bejna wan dirêj e, rûyê wan wek xunçeyê yanî bijkojan ciwan û sor e û axaftina wan xweş û şîrîn e:

Sed hezar Leyla û Şêrîn û Zuleyxa der xiram

Çeşmê şehla, serwî-bala, xunce-dêm elfazê xweş 11/3

\section{c- Gul û bilbil}

Taybetîya herî zêde ku Aqtepî bi gulê ra bikar anîye, têkilîya bi bilbil re ye. Gelek mînakên bi bilbil ra hene lê em ê tenê çend mînakan bidin.

Gul, nîşaneya yarê ye. Bilbil jî remza evîndarê ye ku jê hezdike. Di piranîya helbestan da gul û bilbil tim bi hev ra tên. Bilbil ji ber hezkirina gulê û ji ber êşa dûrbûna ji wê, tim dixwîne. Bi heman awayî helbestvan jî xwe wek bilbil dibîne û dibêje ku ew jî wek bilbil bi êşa dûrbûnê bang dike û dixwîne û qet sebra wî nemaye. Aqtepî dibêje her çiqas derd û dûrbûna ji gulê zor be jî, divê sebir ke. Aqtepî ji bo vê gotina xwe hedîsekê jî bikar tîne û bi vê îbareya Erebî li ser girîngîya sebrê disekine. Wateya "es-sebru mîftah-ul ferec" ev e: "sebr, kilittê rehetîyê ye":

Nalîn dikim wek bilbilan, dûr im bêhna ji sorgulan

Sebr û sikûna bi dilan, es-sebrû mîftah-ul ferec 5/9

Taybetîya bilbil, xwendina wî ya ji bo gulê ye. Dîlber wek gula li gulzarê ye. Aqtepî demeke biharê li gul û kulîlk û baxçeyan dinêre û hemû xweşikîyên di biharê da wek dilberên xweşik difikire. Lê dibêje ku dil li hember van xweşikan yek e û mat maye. Ji ber vê ji xwe ra dibêje ku li hember van gulên li gulzarê divê xweş bixwîne: 
Çunkî ev dilber gulê cûr in di gulzarê cemal

"Rûhîya! Wek bilbilan her dem bibe efxanî geş 11/7

Gul ger carekê dêma xwe an xelekên por nîşan bide bilbil ji kêfa ra li cihê xwe nikare bisekine. Ji xwe derbas dibe, bêheş dibe. Helbestvan ji hîcreta yarê axîna dikşîne û gihisştinê an jî nêrînekê dixwaze ku dilê mirî îhya bibe. Yanî dilê mirî ê bilbil bi rûyê gulê zindî dibe:

Îhya bike vî bêdilî, carek bi dêmê sorgulî

Wek cilweheyê bilbilî, bêtin ji min sed fetl û gerr 10/5

Misle bilbil bêhiş ê yarê gul endam im çira?

Çunkî gêsû helqedar in perçemî 'eyar e gul 14/5

\section{d- Gul û rengê sor}

Gul, bi rengê xwe yê sor û bi şeklê xwe yê giloverik ji bo rû û gupê yarê tê bikaranîn (Durre, 2002: 178; Tolasa 2001: 469; Gölpınarl1, 1945: 23). Sorbûn zindîbûnê û xweşikîyê temsîl dike. Bi rengê xwe yê sor wek rojê dibiriqe û derdora wê ronî ye û xwe jî ronî dike. Çawa ku mirov dixwaze rojê bibîne, bilbil jî ji bo ku bigêje ronahîya rûyê yarê dixebite. Eger carekê jî rûyê yarê bibîne ji kêfxweşîyê nikare li cihê xwe bisekine û tim li ezmên dê bigere:

Îhya bike vî bêdilî, carek bi dêmê sorgulî

Wek cilweheyê bilbilî, bêtin ji min sed fetl û gerr 10/5

Evîndar hezkirîya xwe bi xweşikîya wê dişêbîne gulan. Taybetîya herî navdar a gulê sorbûna wê ye. Ev taybetî ji gelek alîyan ve bi yara mirovan ra tê berhevdan. wek: lêv, gup, rû, ruxsar, can û tenê yarê wek rengê gulê sor tê qebûlkirin (Tolasa, 2001: 125, 220; Şenödeyici, 2014: 14,42,75). Aqtepî di helbesteke xwe da yarê tarîf dike û her taybetîyê bi gulê va gire dide. Di malika mînakî da lêv, gup, rû û bedena yarê bi gulê tê şibandin:

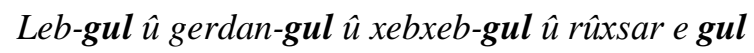

Dêm-gul $\hat{u} c ̧ e h r e-g u l \hat{u}$ ten-gul seraser yar e gul 14/1 
Aqtepî dema behsa xelkê û xemgînîya xwe dike, dibêje ku xelkê yara xwe girt û çûn gerê û bi qedeh, reyhan, gul û sosinan bi hev ra sekinî ne. Li vir mebest ji qedehê dev û lêv in, reyhan pirçên li ser rû û por e, gul jî rûyê yarê ye (Karaalioğlu, 59; Pala, 2009: 376; Cizîrî, 2018: 371).

Îdeyan yarê xwe girtin çûne seyra gulşenan

Muntezir ba saxer $\hat{u}$ reyhan $\hat{u}$ werd $\hat{u}$ sosinan $2 / 5$

\section{e- Gûl û bîhn}

Taybetîyeke herî navdar a gulê bîhna wê ye. Ji ber bîhna xwe pir jê tê hezkirin. Ji ber vê ji gulê gulav tê çêkirin û wek bîhn tê bikaranîn. Çawa ku evîndar dixwaze bîhna yara xwe bistîne, bilbil jî hesreta bîhna gulê ye. Bîhna gulê ji bo evîndêr bîhna rû û zilfa yarê ye. Ev bîhn carinan wek mîsk tê binavkirin. Zilfên bîhnxweş tên ser rûyê sor ê yarê. Bi vî awayî têkilîya rû û bîhnê bi rîya zilfan e. Evîndar eger ji zilfên yarê dûr be, tim dinale. Çawa ku bilbil ji bîhna gulê dûr keve, tim dixwîne ew jî dinale. Lê çare sebr e. Eger evîndar sebir ke hesret ê demekê biqede:

Nalîn dikim wek bilbilan, dûr im bêhna ji sorgulan

Sebr û sikûna bi dilan, es-sebrû mîftah-ul ferec 5/9

\section{f- Gûl û yar}

Gul, ji kulîlkên din cudatir kesayeta yarê bi xwe jî temsîl dike. Yanî gul, ne tenê ji bo şibandina endameke yarê, di heman demê da di şûna yarê da jî cih digire. Aqtepî muhtemelen demeke biharê li kulîlkên xweşik dinêre û helbestekê li ser xweşikîyên cûr bi cûr dinivîse. Biharê wek gulzareke xweşik qebûl dike û dîlberên ku Xwedê xweşik afirandine jî wek gulên di vê gulzarê da qebûl dike. Aqtepî ji ber van dîlberên wek gul ji xwe ra dibêje ku mîna bilbilan kêfxweş be û bang ke. Li vir li ser têkilîya gul û yarê, gul û gulîstanê disekine:

Çunkî ev dilber gulê cûr in di gulzarê cemal

"R̂̂hîya! Wek bilbilan her dem bibe efxanî geş 11/7

Aqtepî di malikeke din da dîsa yarê dişêbîne gulê û dibêje eger roja qîyametê gul jî di baxçeyê cinnetê da tunebe ez naxwazim herim cinnetê jî:

Wextê qiyamet saetê, bê werdê baxê wesletê

Wellahî naçim cennetê nadim li Firdewsê nezer 10/2 
Dema meriv bi yara xwe ra be jîyan wek cejn û eyd e. Eger meriv ne li ba hezkirîya xwe be, ew roj cejn be jî meriv nikare kêfxweş be. Aqtepî kêfxweşîya xelkê -çi mezin be çi biçûk- dişêbîne kêfxweşîya gul û bilbilên ku li ba hev in û bi hev ra li bihara xweşik temaşe dikin. Bi hevrabûna evîndar û hezkirîyan wek cejn şîrove dike. Dibêje ku herkes mîna bilbilan li ba yara xwe ye, her bilbil bi gula xwe ra ye. Lê bi xwe ji yara xwe dûr e. Bi vî wayî Aqtepî ji dûrbûna yara xwe, ji xemgînîya xwe gazincan dike:

Îd e keyf $\hat{u}$ şahî ye nêv xas $\hat{u}$ 'amê xulxul e

Yekyekan aşiq li ser sorgul mîsalê bulbul e 2/3

$\hat{I} d$ e, nik xelqê temaşa ye wekî fesla bihar

Nexmexwîn in her kesek ber werdê weslet sed hezar 2/17

Di vê malika jor da Aqtepî ji bo gulê bêjeya "werd"ê û ji bo bilbil jî bêjeya "hezar" bikar anîye. Wek ku tê zanîn bêjeya "hezar", tê wateya "bilbil" jî (Tolasa, 2001: 301, 454; Durre, 2002: 245, Kurnaz, 1987: 485). Dibêje ku bi hezaran bilbil ji bo gula xwe stranan dibêjin.

Armanca evîndar tenê hezkirîya xwe ye. Her gav wê difikire. Aqtepî jî hezkirîya xwe şibandiye gulê. Çawa ku bilbil tim gulê difikire û ji bo wê dixwîne, Aqtepî dibêje ku wek bilbil zikr û xwendina me jî tim gul e:

Yarê min terkîba endamê gul e, yekser gul e

Werdê min daîm gul e, hem qelbê min efkar e gul 14/11

Cudabûna ji yarê mîna tîran dil birîndar dike. Ji ber vê evîndar mîna bilbilan dinale:

Xedenga firqetê da dil, dinalim şubhetê bilbil

Ji hicra xunçeya sorgul, dikêşim cewr û zîbaê 26/8

Carinan helbestvan xwe û bilbil dide hember hev, evîna xwe, ji a bilbilan xweştir dibîne. Di çavê evîndar de gul û hezkirîyek tenê heye, ew jî a wî bixwe ye. Gulên ku bilbil jê ra meyl dikin vala ne, bê wate ne. Li vir Aqtepî îşareta hezkirîya rast xwedê dike û dibêje ku tenê xwedê gul û hezkirîya rast e. Ên 
dinyewî ne rast in, mecazî ne. Bi vê gotinê helbestvan li ser evîna rast û mecazî disekine:

Fîl heqîqet gul yek e, ev nazika şeng $\hat{u}$ şepal

Bilbilan bêhûde meylê werdê der bustan dikin 21/13

Evîndar eger bigêje zilf û perçînên yara xwe êdî qîmet û rûmeta mîsk û gulan namîne. Aqtepî li vir gul û endamên yarê dide ber hev:

Qîmeta mişka Tetarê, rûmeta werda biharê

Kirye napeyda bi zarê, zulf û perçînê di min 22/14

\section{g- Gul, bax û bihar:}

Carinan jî gul tenê xemla gîya, mêrg û biharê ye. Wek endameke ji xwezayê tê behskirin. Bi vî şeklî gul, nîşaneya geşbûn û xweşbûna biharê ye. Di dîmeneke wiha xweşik da divê mirov kêfxweş be, lê Aqtepî dibêje ku eger dîlbera min tunebe dilê min nare tiştekî:

\section{Sosin û sorgul di çîmen restinê fesla bihar}

Dilber im peyda nehin meyla me yekser nare tê $27 / 2$

Qîmeta mişka Tetarê, rûmeta werda biharê

Kirye napeyda bi zarê, zulf $\hat{u}$ perçînê di min 22/14

\section{Nesrin}

Navên wê yên din Nestern, Nesteren, Nesterîn e. Cureyeke kulîlka nêrgîzê ye. Rengê kulîlkê zer an spî ye û bîhnxweş e. Xwedîyê pelên dirêj û xêzxêzî ye. Di daristanan da û li cihên bi şilî bi xwe şîn dibe. Gula kovî jî tê gotin. Di çêkirina bîhnan da tê bikaranîn. Ev kulîlk di bihar û havînê da dest bi mezinbûnê dike û di nîvê zivistanê de kulîlkan dide (Enverî, Ferheng-i Rûz-ı Suhen, 1383: 1252; Mûîn, 1376: 4721; Cizîrî, 2018: 232, 301; Onan, 1991: 515). Ji havînê heta zivistanê dora du mehan radikeve û di zivistanê de kulîlkan dide. Jê ra kulîlka zivistanhez jî tê gotin. Cinsekî wê li çolan jî mezin dibe. Ji ber vê jê ra gula çolan, gula tebaxê û gula kovî jî tê gotin. Bingeha xwe ji başûrê Emerîkayê ye. Sê şaxan dide û di her şaxekî da ji diduyan heya şeşan kulîlk derdikevin.

Di wêjeyê de bi rengê xwe yê spî, zer, û sor û bi bîhna xwe xweş tê behskirin. Bi rengê xwe wek gul û yasemînê ji bo rû û gupê yarê tê bikaranîn. Bi rengê xwe wek çavkanîya ronahîyê tê hesibandin. Ev şibandina ronahîyê jî ji taybetîya rûyê yarê tê. Ji ber ku rûyê yarê di heman demê de wek roj û heyv ronî ye. Roj û heyv jî rengên vê kulîlkê temsîl dikin. Bi ronahî û spîtîya xwe tiştên 
wek hêstir, dilop û kincên spî ji bo nêrgîzê tên bikaranîn. Ev kincê spî carinan dikare kefen be jî (Avşar û Cengîz, 2017: 68; Enverî, Ferheng-i Kinâyât-ı Sohen, II, 1439; Pala, 2009: 67, 116; Tarlan, 1998: 1998: 500; Tolasa, 2001: 2001: 353; Cizîrî, 2018: 232, 301). Carinan ji bo tenasubê tenê bi kulîlkên din ra û bi bax û biharê ra tê. Di tesewwufê da xweşikîyên xêncî xwedê yanî masîwayê temsîl dike.

\section{a- Sipîtî û ronahî}

Nesrîn, di dîwana Aqtepî da li du deran derbas dibe. Bi rengê xwe yê spî ronahîyê, gup û rûyê yarê nîşan dide. Bi heman wateyê bi gulê ra pir tê gotin. Li dijî wê jî reşahî heye ku Aqtepî ew bi zilfên yarê gotiye. Di malika jêr da nesrîn bi gulê ra ronahîyê û bi zilfa reş ra spîtîyê nîşan dide:

\section{Zulfê meşkin da du sed te'ne li nesrîn û gulan}

Îd $\hat{u}$ newrozên li min da çerxê etles xulxuland 4/11

\section{b- Nesrîn û yar}

Kulîlk wek ku tê zanîn carinan wek parçeyek ji xwezayê, carinan ji bo endamên bedena yarê û carinan jî bi tevahî di şûna yarê da tê gotin. Aqtepî li cihekî li ser rûnîşandan û nêrîna yarê disekine. Rûyê yarê bi perdeyê veşartî ye. Lê ev perde porê reş ê yarê ye. Dema ku yar rûyê xwe ji nav zilfan derxe û rawer ke û cîlweyên xwe bi vî awayî nîşan bide evîndêr, nêrînên wê wek tîr û teber êrîş dikin ser wî. Di malika duyem da wek wateya yekem dibêje dê yar ji paş perdeyan derkeve. Lê kesê ku ê derkeve yanî yara xwe wek nesrîn bi nav dike. Bi vî awayî yar û nesrîn di cihê hev da hatine bikaranîn. Li vir derketina yarê bi derketina nêrgîz û gulê hatiye mînandin:

Saeta yar cîlweger bê, bi xencer $\hat{u}$ tîr $\hat{u}$ teber bê

Dê ji ber perdan bi der bê, werdê nesrînê di $\min 22 / 19$

\section{Lale}

Navê cureyên gîyayekî ye. Ji malbata sosinîyan e û ji cureya Tulîpan e. Wek kulîlkên xemlê tên mezinkirin. Koka xwe bi şeklê pîvazê ye (Devrim, 1999: IV, 2033). Di biharê da vedibe, di payîzê da tê çandin. Zêdetir li cihên ku axa xwe bi xîz û zibil e mezin dibin. Ji bo dermankirina nexweşîyan jî̀ tê bikaranîn. Ev kulîlk sor û zer û rengên di navbera wan da ye.

Derheqê laleyê da çîrok û efsaneyên curbicur tên vegotin. Hinek dibêjin ku li ser pelê laleyê dilopa avê hebûye. Dema brûsk lêketîye pelê wê şewitîye. Paşê ew dicemide û dibe lale. Dibêjin ku ew reşahîya di navenda kulîlkê da jî bermahîya wê şewatê ye. Di çavkanîyên rojavayî da tê gotin ku xwedayê roj û gîyayan 
Adonîs dema ku dimire xwîna xwe dirijê erdê û bi wê xwînê ev lale şîn bûye. Yanî dîsa di mîtolojîyê da jî têkilîya reng û xwînê heye.

Di wêjeyê da bi piranî bi rengê xwe yê sor, bi rengê reş ê di navendê da û bi şeklê xwe tê behskirin. Sorbûna pelên wê, reşbûn û şewitîbûna mayîna xwe ku wek dil li navendê cih digire, nîşaneya êş, derd û şewitînê ye. Ji ber vê wek laleya daxdar yanî laleya şewitî tê zanin (Yıldırım, Nimet, 2008: 483; Tolasa, 2001: 220, 448, Tarlan, 1998: 335). Biwêjên wek xwînîbûna kezebê, şewitîna dil û herwekî din ji ber vê tên bikaranîn. Dema ku reng û şekl bi hev ra were fikirîn teşbîha qedeh û şerab tê çêkirin. Bi vî alîyî jî remza qedeha şerabê û birîna li ser sînga evîndar e. Ji ber rengê xwe yê sor, rû û gupê yarê û hêstirên evîndar bi laleyê va tên şibandin (Devrim, 1999: IV, 2033; Padişah, 1346: 203; Talibiyan, 1382: 181; Tolasa, 2001: 215). Wekî din reşahîya di navberê da wek xala li ser rûyê yarê ye. Lale dema ku were qutkirin hema dimire. Ji ber vê jîyan û umrê kin temsîl dike (Aslanoğlu, 2018: 459).

\section{a- Lale û rengê sor}

Lale her çiqas çend rengên wê hebin jî bi piranî bi rengê xwe yê sor wek gulê ji bo rûyê yarê tê bikaranîn. Rengê sor xweşikîyê, zindîbûnê û ciwanîyê nîşan dide. Helbestvan teswîra biharê dike û kulîlkên li baxçeyan bi zêdebûna wan dişibîne stêrka Perwînê ku şeş an heft heb in. Ji hebûna kulîlkên laleyan wek keçên rûlale behs dike. Bi vê şibandinê lale û rengê sor têkildar dike:

Mislê perwîn e sema cem in di çîmen lale-rîu

Fewcefewc in der temaşa heft $\hat{u}$ heyş̧t $\hat{u}$ pênc $\hat{u}$ şeş 11/6

\section{b- Xweşikî}

Gelek helbestvan bûyerên rind an tiştên xweşik bi xweşikîya yarê va girê didin. Bi vî awayî hunera husna te'lîl yanî xweş-sedemîyê çêdikin. Aqtepî jî dema mezinîya xweşîkîya yarê tîne zimên dibêje ku gelek kulîlkên bêhnxweş ên wek rihan û laleyê bîhna xwe ji yarê distînin û ji ber wê herkes ji bîhna wan hez dike:

Rihan $\hat{u}$ lale $\hat{u}$ qetmer, zibad $\hat{u}$ mawer $\hat{u}$ anber

Ji rengê buyê te yekser, ezîzin ew ji xelqê ra 1/20

\section{Nêrgîz}

Jê ra di latînî da "Nergisus", di Firensî da "Narsis"; di Erebî da "Nercis" û di Farsî da "Nergîs" tê gotin. Nêrgîz wek lale û simbil gîyayekî serikî ye. (Devrim, 1999: V, 2439). Kulîlkên wê bi bîhneke bi bandor in, reng zer û spî ne. Di navenda her kulîlkê da taceke zer an spî heye. Bi piranî wek gîyayeke xemlê tê mezinkirin. Serikên xwe jehrî ne. Pelên li dorê ên tacî şeş heb in. 
Di mîtolojîya Yunanîyan da çîrokek li ser nêrgîzê tê gotin. Tê gotin ku qehremanekî Yûnanî bi navê Narkissos yekî xwehez e. Rojekê li daristanê dema ku digere li avekê dinêre û xwe dibîne û evîndarê xwe dibe û xwe berdide avê û dimire. Perî dema ku li cinazeyê wî digerin dibînin ku di avê da kulîlkeke reng û bîhnxweş şîn dibe. Ji wê kulîlkê ra nêrgîs dibêjin. Ji ber vê nêrgîz, nîşaneya xwehezîyê ye jî (Atan, 2011: 137, 404; Pala, 2009: 356).

Ji ber şeklê xwe û efsaneya mîtolojîk bi piranî di wêjeyê da bi çêv ra têkilî tê çêkirin. Ji nêrgîzê kînaye çavê yarê ye. Dilopên çavan jî wek nêrgîz tên fikirîn. Şeklê xwe wek kesê hustîxwar e. ji ber ku pelên vê kulîlkê tim verkirî ne, wek kesê ku tim şiyar be û qet ranekeve tê fikirîn. Bi vê nêrînê têkilî bi mestîyê û çavbixewîyê ra çêdibe (Pala, 2009: 356; Hevarî, 1995: 40; Afîfî, 1359: 2483; Horremşâhî, 1387, 450; Azad Meniş ve Şerîfî-b, 1391: 27; Nasıf ve diğerleri, 2004: 123; Tolasa, 2001: 481). Têkilîya nêrgîzan ya bi çavê mest ra ne tenê bi van sedeman e. Wekî din tê zanîn ku di koka nêrgîzan da taybetîya haşî̧î yanî esrarî heye. Ji ber vê alîyekî rast ê serxweşîyê jî heye. Di wêjeyê da bi taca zer a li ser jî pir tê behskirin. Dema biharê wek ku nêrgîzê taca xwe danîbe ser serê xwe (Aslanoğlu, 2018: 463).

\section{a- Mexmûrî}

Taybetîya herî mezin a nêrgîzê, şibîna çavên yarê ye. Lê çavê herî xweşik jî çavê mexmûr yanî bi xew û mest ku tam ne şîyar e. Evîndar wan çavên şîîn û mexmûr dixwaze û ji ber wan dibe esîrê evînê:

Temenna nêrgiza mexmûr, şeraba cewhera engûr

Dil û canê me kir rencûr, kirim yexsîrê sewdaê 26/19

\section{b- Xweşikî}

Nêrgîz ji wan kulîlkan e ku ji bo teswîra xweşikîya yarê pir bi kar tê. Lê wek ku tê zanîn evîndar eger bi evîna yara xwe keve, êdî xweşikîya nêrgîzê jî li ber çavê wî namîne û dilê wî naçe tu kulîlkan:

\section{Meylê dil çewa biçit ser purpizêk û nêrgizan}

Çûn ji hicrê yarê serkeş ketme pêk $\hat{u}$ herqetê 27/3

\section{Sosin}

Di Farsî da sûsen û di Kurdî sosin tê gotin. Pelên wê zirav û dirêj in. Welatê wê yê kev Emerîkaya Başûr e. Rengên cuda yên wê hene. Zer, sor, spî, pembe û 
turuncî ne. Bi piranî bi serikên wek pîvazan tên çandin. Li malan jî wek kulîlkên xemlê tên mezinkirin.

Di wêjeyê da ji ber şeklê xwe yê zirav û dirêj wek zimên tê fikirîn û têkilî bi axaftinê ra jî tê çêkirin. Bi vê nêrînê bi kesên ku xwedî ziman in lê nikarin bipeyivin tê şibandin. Bi vî awayî kesên lal jî nîşan dide (Destkong, 1391: 20; Şefi' Hânî, 1389: 17). Dema ku navê wê derbas dibe behsa gotin û xwendinê tê kirin. Bi vî alîyî sosin dikeve cihê kesên ku dipeyin jî. Carinan bi rengê xwe yê spî û zer jî cih digire. Rengê spî bi piranî wek kulîlkên din bi ronahîya xwe ji bo rû û gupê yarê an kincan tê bikaranîn. Bi heman wateyê tiştên rind û bixêr bi rengê spî tê gotin. (Mehdevifer, 1392: 129; Mehdevîfer, 1391: 70). Dema behsa bihar, baxçe û keskahîyan tê kirin navê wê, bi kulîlkên din ra tê gotin.

\section{a- Xemla biharê}

Di dîwana Aqtepî da sosin li her derê wek xemla biharê bi xweşikîya xwe hatiye behskirin. Aqtepî sosin û gulan wek parçeyeke biharê dijmêre. Bihar bi mêrg û kulîlkan li ber çavan pir xweş dixuye. Lê eger evîndar di vê dîmena xweş da ne li ba evîna xwe be an yara wî xuya neke û ew jê dûr bimîne tu xeml û xweşikî wî kêfxweş nake, meyla wî li ser wan sosin û gulan jî nabe:

Sosin $\hat{u}$ sorgul di çîmen restinê fesla bihar

Dilber im peyda nehin meyla me yekser nare tê $27 / 2$

Bi heman wateyê di wê bihara xweşdîmen da çiqas gul, sosin, binefş û purpizêk hebin jî di dilê evîndêr da, li ba sohbeta yarê ne xwedîyên tu qîmetî ne, bi pereyekî nakin. Ji bo evîndaran eger yar hebe tiştên nebaş jî baş xuya dikin; lê eger yar tunebe her tişt hebe jî bê wate ye û tu xweşikî li ba tehma sohbet $\hat{u}$ dîtina yarê, xweş xuya nake:

Sed gul $\hat{u}$ sed sosin $\hat{u}$ sê sed binevş $\hat{u}$ purpizêk

Yek pere nayê li nik dil ew di sûka mehbetê 27/4

\section{b- Sosin û yar}

Sosin an kulîlkên din ên wek gul û binefş bi taybetîyên cuda tên behskirin. Yek ji wan jî ketina şûna yarê ye. Yanî sosin yar e, evîn e, hezkirî ye. Aqtepî dema kêfxweşîya xelkê û xemgînîya xwe dike dibêje herkesî yara xwe ya reyhan û gul û sosin girtin çûn baxçeyan û di destê wan da qedehên şerabê hene, lê ez bê yar tenê mame:

Îdeyan yarê xwe girtin çûne seyra gulşenan

Muntezir ba saxir $\hat{u}$ reyhan $\hat{u}$ werd $\hat{u}$ sosinan 2/5 


\section{Reyhan}

Jê ra Îsperxem, îsperhem, şahê îsperem, nazbû û zemîran jî tê gotin. Wek gîyayê reyhan jî tê zanîn. Bi piranî cihên germ û hişk hez dike. Li dijî sermayê hessas e. Welatê wê Îran û Hindîstan e. Koka xwe rast e, bêpirç an pirç pir hindik in, pirşaxî ye û bi pel e. Pelên wê bîhnxweş in. Pembe û spîreng in (Yıldırım, Nimet, 2008: 639; Devrim, 1999: II, 1047). Meyweyên wê biçûk û bi reşahîyeke birqonekî ne. Pelên wê kesk an mor in. Ên mor wek reyhana reş jî tê binavkirin. Di çêkirina bîhnan da, ji bo zêdekirina bandora vexwarinên wek şarab û şerbetê tê bikaranîn. Wekî din ji bo dermanan jî jê tê îstîfadekirin. Reyhan di heman demê da navê cureyeke nivîsê ye.

Di wêjeyê da bi piranî bi bîhna xwe bikar tê. Ji bîhnê şunda reng û şeklê wê tê. Por, zilf û pirçên ziravik ên zerik ên li ser rûyê yarê bi reyhanê va tên şibandin (Pala, 2009: 376; Karaalioğlu, 1975: 142; Tarlan, 1998: 1998: 142, 272). Di van şibandinan da jî bi piranî bîhn û reng girîng e. Destekirina reyhanan jî wek gulîyên por tê hesibandin. Ji ber ku tê wateya cureya nivîsê, carinan bi têkilîya nivîsê jî tê behskirin.

\section{a- Reyhan û zilf}

37 Têkilîya herî zêde ku bi reyhanê tê çêkirin, reng û bîhn e. Ji alîyê rengê va reyhan bi piranî wek reş tê gotin, ji alîyê din va jî bi bîhna xwe ya xweş tê behskirin. bi her du taybetîyan reyhan bi zilfê ra têkildar dibe. Ji ber ku zilf him reş e, him jî bîhnxweş e. Bi piranî li ser şibîna van her duyan tê sekinîn. Lê Aqtepî di malika jêr da zilfê ji reyhanê mezintir digre û zilfa yarê tinazan bi reyhanê dike dibêje:

Aşiqan pur dîn sedeq, ez bilbilê dilber ji gul

Zulfê mişkîn te'neha der sunbulê reyhan dikin 21/15

\section{b- Reyhan û yar}

Kulîlk pir caran ji bo xweşikîya endamên cuda cuda ên yarê tên gotin. Lê carinan jî rasterast dikevin şûna yarê û hezkirîyê. Reyhan jî bi bîhna xwe ya xweş û bi pelên xwe yên wek zilf, bi rengên xwe yên xweşik wek yarê ye. Herkes bi yara xwe ya wek reyhan û sosin ra ye, lê şaîr ji evîna xwe dûr e:

Îdeyan yarê xwe girtin çûne seyra gulşenan

Muntezir ba saxir $\hat{u}$ reyhan $\hat{u}$ werd $\hat{u}$ sosinan $2 / 5$

Rihan her çiqas bîhnxweş be jî bi rastî ji ber bîhna yarê wisa xweşik in: 
Rihan $\hat{u}$ lale $\hat{u}$ qetmer, zibad $\hat{u}$ mawer $\hat{u}$ anber

Ji rengê buyê te yekser, ezîzin ew ji xelqê ra 1/20

\section{Nebat}

Nebat bêjeyeke Erebî ye û di wateya gîya da ye. Lê wateya duyem jî gîyayê qamişê ye. Jê ra ney, nay û nal jî tê gotin. Ev nav bi Farsî ye. Bi Erebî jê ra Qasab tê gotin. Wek qamişê şekir jî tê zanîn. Lewra di nav van qamişan da aveke şîrîn heye û berê ji vê avê şekir dihat bidestxistin. Ji bo welatên germ ev qamiş gîyayekî girîng e. Yek ji van welatan jî Misir e. Li van welatan ava qamişan wek şerbeta herî navdar û erzan e. (Mutçalı, 1995: 708; Omar, 2008: 1818; Ma luf, 1956: 632; Tolasa, 2001: 93). Ji vî qamişî aleteke muzîkê ya pifkirinê ku li kêlekê qulik hene û bi şeklê lûleyekê ye tê çêkirin. Bi pifkirinê û bi tevgereke bi pergal û aheng a tilîyan tê lêxistin. Ji ber ku ji qamişê hatiye çêkirin ev nav li vê aletê hatiye kirin (Omar, 2008: 2152; Kam, 1998: 35; Çelebioğlu, 1998: 532, 536). Qamiş wek şerbetê bi şîînbûna xwe û wek aleta muzîkê bi dengê xwe derdikeve pêş.

Di wêjeyê da bi şîrînbûna xwe ji bo hin endamên yarê tê bikaranîn. Ji van şibandinan tiştê herî navdar lêv û gotinên yarê ne. Taybetîya duyem dengê neyê ye ku bi piranî ji bo axîna evîndar wek hêmana şibandinê tê bikaranîn. Tiştê ku neyê dide zarkirin, evîn e. Ney, bi meya şîrîn serxweş e û bang dike. Ji ber vê li ser şibîna ney û meyê jî huner tên çêkirin (Tolasa, 2001: 65; 536; Onan, 1991: 437). Qamiş, bi têkilîya pênûsê gelek tê behskirin. ji ber ku ji qamişan pênûs tên çêkirin.

\section{a- Nebat û lêv}

Nebat, bi wateya xwe ya qamişê herî zêde ji bo şîrînbûna xwe tê behskirin. Bi şîînbûna xwe jî ji bo lêvên yarê û axaftina yarê wek hêmana şibandinê bikar tê. Ev lêva şîrîn a yarê ji bo evîndêr wek ava jîyanê ye. Lê hezkirî, dil-kevir e û ji evîndêr dûr e. Ji ber wê evîndar bê ava jîyanê dimire:

Sengî qelb û leb-nebatê, bir ji min ismê heyatê

Her dema badê seba tê, taze ne birînê di min 22/12

\section{b- Gîya}

Helbestvan behsa derketin evîna xwe dike. Dema ku ew yar ji eywanê rûyê xwe nîşan dide û wek rojê hiltê hemû alem dar û nebat yanî gîya bi ronahîya wê ronî dibin. Li vir nebat bi wateya gîyayên ji rêzê ji bo hemû cureyan hatiye gotin:

Zînet $\hat{u}$ xemla mubarek xawera şerqê hilat

Eks $\hat{u}$ nîşan in tedarik xemilîn dar $\hat{u}$ nebat $4 / 2$ 


\section{Piyaz-pivaz}

Bi Farsî "pîyaz", bi Kurdî/Kurmancî "pîvaz" û bi Erebî "basal" tê gotin. Ji malbata nêrgîzîyan e. Welatê vî gîyayî Rojavaya Asyayê ye. Wek serik di bin axê da tê çandin û pelên kesk derdikevin derve. Him pelên xwe yên kesk him jî koka xwe ya di bin axê da tê xwarin. Pelên xwe kesk tên xwarin, lê serikê xwe tê hişkkirin û hişk tê xwarin. Bîhna xwe gelek bi bandor e. Ji ber wê bîhna wê mirovan aciz dike. Tehma wê tûj e.

Di Qur'anê da di sûreya Baqarayê da derbas dibe. Lawên Îsraîlîyan ne'metên ku Xwedê dane naecibînin û ji Mûsa ra dibêjin ku ji Xwadê beqle, encûr, sîr, nîsk û pîvazan dixwazin (Bnr. Baqara, 62). Di ayetê da li hember xwarinên xweş wek xwarineke ne hêja derbas dibe. Û dîsa bi vê bûyerê ra têkildar ji bo rexneya yahûdîyan tê gotin.

Di wêjeyê da zêde behsa pîvazê nayê kirin. Bi piranî di helbestên civakî da wek nîşaneya feqîrîyê tê behskirin. Ji ber ku feqîr bi piranî nan û pîvazê bi hev ra dixwin. Bi vî awayî pîvaz û nan bi hev ra tê gotin (Bnr: Yeniterzi, 2013: 437). Bi bîhna xwe ya nebaş ji bo berhevdana bîhna xweş a yarê tê gotin. Bi vê mebestê kulîlkên bîhnxweş, mîsk, anber û pîvaz bi hev ra tên (Sefercioğlu, 1990: 87, 94; Mevlana, 1995: 459). Pîvaz bi bîhna xwe meriv aciz dike, lê eger xirab bibe zêdetir dîmeneke nebaş derdikeve holê. ji ber vê ji bo tiştên kirêt û nexweşik jî tê bikaranîn û bi dijberîya tiştên rind tê behskirin.

\section{a- Bêqîmetî}

Ji bo evîndar armanca jîyanê, gihîştina yara xweşik e. Eger bigêje wê yara spî û xweşik êdî hemû dinya li ber çavê evîndar bi qasî pîvazekê jî bi hêja ye. Li vir pîvaz bi bêqîmetîyê derketîye pêş:

Ger muzaffer bim bi wesla dilberê gerden-beyaz

Her du alem nayê ber çeşmê me qîmet yek peyaz 4/34

\section{Serwî}

Ev dar, di her demsalê da zindî dimîne û pelan naweşîne. Gelek cureyên wê hene. ên herî navdar ku tên behskirin ev in: Serwîya naz, serwîya sehî (rast), serwîya azad, serwîya kûhî (çîyayî), serwîya soxdar, serwîya Lubnanî. Li welatê Başûrê Ewrûpayê zêdetir e. Di du salan da mezin dibe. Li gorîstanan û li park û ber rîyan tên çandin (Musahib, 1380: I, 1289; Tuğlac1, 1985: VIII, 1559, 2558). Ev dar li cihên avî şîn dibe û ji avê pir hez dike. Ji bo wê zû dirêj dibe.

Di wêjeyê da dara ku herî zêde ji bo yarê te gotin ev e. Bi dirêjîya xwe bejna yarê nîşan dide. Dema ku ba lêdixe û hêl dibe dişibe yara ku bi nazdarî dimeşe (Korkusuz, 2005: 152; Durre, 2002: 177; Tuğlacı, 1985: VIII, 2559; Tarlan, 1998: 62). Pelên wê dema ku bi bê dihejin wek ku porê yarê ber bayê keve. Ji 
ber ku di her demsalê da kesk e alema ebedî nîşan dide. Ji ber vê taybetîyê di gorîstanan da pir tê çandin. Bi bejna xwe ya dirêj hilkişîna alema ebedî temsîl dike. Dîsa ji ber ku bejna xwe dirêj û rast e, rastbûnê nîşan dide. Serwî di teswîran da tim li ber av û çeman û bi mêrg û baxçeyan tê behskirin. Di tesewwûfê da bi bejna xwe ya wek elîfê û wek jimara yekê tê wateya wehdeta Xwedê.

\section{a- Serwî û bejn}

Serwî di hemû malikan da ji bo bejna dirêj a yarê hatiye gotin. Di gelek malikan da helbestvan taybetîyên endamên yarê dibêje. Yek ji van jî bejna yarê ye. Bejna yarê herî zêde bi dara serwîyê va tê şibandin:

Qed serwe, gerden sade 'ac, eswed'uyûna ser bi tac

Naket li derdê min ilaç, es-sebru mîftah-ul ferec 5/15

Sed hezar Leyla û Şêrîn û Zuleyxa der xiram

Çeşmê şehla, serwî-bala, xunce-dêm elfazê xweş 11/3

Bi qurban ew qeda wekî serwê baxan

Bi heyran xalê reş teşbîhê zaxan 20/9

\section{1. 'Er'er}

Ar'ar jî tê nivîsandin û xwendin. Er'er cureyeke serwîyê ye. Ji ber ku li çolê û çîyayan şîn dibe jê ra er'era çîyayî tê gotin. Ev jî wek serwîyên din li dijî sermayê berxwedêr e û zexm e. her demsalê kesk û zindî ye. Pelên wê zivistanê jî naweşin (Cîhanî, 2013: 377; Mâzenderânî, 1377: 568; Pala, 2009: 25). Pelçên wê mezin in û zêde ne. Dareke pir zexm e. Berê ji bo sergirtina malan jî dijat bikaranîn.

Di wêjeyê da xwedîyê taybetîyên dara serwîyê tê. Herî zêde ji bo bejna yarê wek hêmana pêşibandinê tê bikaranîn. Dema behsa bejna yarê tê kirin, wek îstîare serwîya er'êrê an er'er tê gotin. Ji bo bejna yarê bi wê ra, navê darên şimşad, serwî, çinar, sanevber û tûba jî carinan bi tenasubê tê anîn. Bi dirêjbûna xwe têkilî bi ezmanan jî tê çêkirin. Ji ber keskmayîna herdemî têkilîya bi ebedîyetê ra jî tê behskirin (Zavotçu, 2012: 17; Tolasa, 2001: 271; Sefercioğlu, 1990: 200, 402; Fûladî ve Mansur, 1389: 136). Hêmaneke din ku bi er'erê ra tê behskirin, ba ye. Ji ber ku er'er bi bejna dirêj bi bayê ra hêl dibe. Ev hêlbûn wek meşa yarê a bi naz e. 


\section{a- Er'er û bejn}

Di helbesta klasîk a wêjeya dîwanî da çawa ku bi piranî er'er ji bo bejna yarê tê bikaranîn, Aqtepî jî bi heman awayî dema ku behsa endamên yarê dike ji bo bejna wê dara er'erê tîne zimên. Bi vê şibandinê bal dikşine ser bejna dirêj a yarê:

Çeşmê hûrî, werdê curî qedd û qamed 'er'erê

Der lehîbê ateşê ez ketme pencê beglerê 13/11

\section{2. Şimşad}

Şimşîr jî tê gotin. Dareke ji malbata şimşîrîyan e. herdem wek devîyên kesk û daran e. Kulîkên wê bi rengê zerê keskî ne. Darê wê pir hişk, têkûz e, rast, birqonek û zexm e. Ji darê wê gelek cureyên mobîlyayan û alavên wek şeyên por tên çêkirin. Ji ber ku di her demsalê da kesk e wek serwîyê jîyana ebedî nîşan dide. Lê bi qasa serwîyê ne zirav û rast e. Ji ber têkilîya bi ebedîyetê, nemirinê û herdem zindî mayînê li gorîstanan pir tê çandin (Afîfî, 1359: 1359: 1717; Yıldırım, Nimet, 2008: 663; Çelebioğlu, 1998: 171; Cizîrî, 2018: 230).

Di wêjeyê da wek serwîê û er'erê ji bo bejna yarê, ji bo meşa wê ya nazdar û hêlhêlkî tê bikaranîn. Lê ji ber ku bi qasa serwiyê ne zirav û rast e wek wê nikare bi nazdarî bimeşe. Ji ber ku bejndirêj e bi bayê hêl dibe. Ev hêlbûna darê 41 dişibe meşa mestî ya yarê. (Tunç, 2010: 256, 306; Tarlan, 1998: 144, 184; Çeçen, 2008: 135).

\section{a- Şimşad û bejn}

"Fikra evîndêr tim yara xweşik e. Taybetîyeke navdar a yarê jî bejna wê ya dirêj e. Ew jî bi bejna şimşadê ye. Evîndar şev û roj yara xwe ya bejindirêj difikire. Aqtepî bi îfadeya qameta şimşadî li ser bejna yarê sekinîye:

Fikrê min ew qameta şimşadî ye der roj $\hat{u}$ şeb

Roz $\hat{u}$ şeb yeksane yekreng e ji bo min der teleb 13/4

Aqtepî di helbestekê da pesna şahê Nexşîbend dike. Di her malikê da wî li ser her tiştî xweştir nîşan dide. Ezmanê bilind bi duaya wî li ser pîyan e û ewqas bilind e. bilindîya ezmanan ji bilindîya wî ye. Ew canê cananê cîhanê ye û xemla baxçeyê şimşîran e. Aqtepî di malika jêr da Nexşîbendî wek xemla baxçeyên şimşadê nîşan dide. Yanê darên şimşadê bi saya Nexşîbendî ewqas serbilind in:

Asîman ber pastê ez dest duayê Nexşîbend

Canê cananê cîhanê zibendeyê şimşîrîgah 6/33 


\section{3. Çîmen}

Çîmen, ew gîyaye ku li der doran bi serê xwe derdikeve û mezin dibe. Li hinek cihan jî ji bo cihên ku dor hatiye girtin, bi kulîlkan hatiye xemilandin û ji bo rûniştina mirovan hatiye amadekirin tê gotin. Bi van taybetîyan çîmen pir caran wek baxçe tê bikaranîn. Bi rengê xwe yê kesk derdikeve pêş. Pir caran bi gul, bilbil, av û çeman ra tê gotin (Tarlan, 1998: 674; Nebî Lû, 1394: 249). Tê wateya keskahîyê jî. Carinan ji bo dinyayê, ezmên û felekê jî tê bikaranîn. Kulîlk û serwî û gul, pê ra bi tenasubê tên. Di tesewwûfê da tê wateya rehmet û bexşandina Xwedê.

\section{a- Baxçe}

Şaîr behsa biharê, rengînîya kulîlkan a meha nîsanê dike û pirrengîya wan a li nav çîmen dide ber çavan. Li vir jî wek baxçeyê kulîlkan ku reng reng kulîlk tê da hene hatiye nîşandan:

Wek di nîsan rengereng, çîçek vebin der murxîzar

Muxtelit bûn têk di çîmen leşkerê Rom û Hebeş 11/2

\section{Engûr}

Bi Farsî engûr, bi Erebî îneb tê wateya meyweyê tirî. Ev navê meyweyê gîyayekî bi mêw e. Dîroka çandina tirî digêje berîya mîladê 5 hezar salan. Bi hezaran cureyên wî hene. Bi piranî bi rengê zer, zerê vekirî, kesk (sipî), pembe, sor, mor û reş e. Bi guşîyan li ser mêwê digire (Merdûx Rûhanî, 1385: 268; Kilıçlıoglu ve diğerleri, 1986: XX, 46). Berîya gihîştinê tirş e, dema ku dema xwe tê û digêje şîrîn dibe. Meyweyekî şîîn û avî ye. Gelek cureyên xwarinan jê çêdibin. Bi işkkirinê mewij çêdibe. Xencê wê ji ava wî dims, qirme, bastiq çêdibe. Ji tendurustîyê ra, bi taybet ji bo çermê meriv pir bi fêde ye. Wekî din jî şerab ji ava tirî çêdibe. Ji tirîyê reş şeraba sor, ji tirîyê spî jî şeraba spî çêdibe ku ev ji ber serxweşkirinê di Îslamê da heram e (Sarı, 2016: 268; Korugan, 2001: 100).

Di wêjeyê da tirî bi piranî bi alîyê şerabê tê behskirin. Ji bo îşaretkirina şerabê carinan bir rengê xwe yê zer û spî derbas dibe (Nihânî, 1394: 54,64). Şerab bi şîrînbûna xwe û rengê xwe yê sor ji bo lêvên yarê tê gotin. Hebikên spî wek rûyê yarê ne û şaxên li dor hebikan jî wek zilfan in. Hebikên mezin û reş dişibin çavên yarê. Guşîyên tirî bi rêzbûna li dor hev dişibin stêrka sureyyayê ku komek e (Gülendam, 2008: 495-496; Mum, 2006: 132, 135). Ji alîyê tesewwûfî va bi şeraba îlahî tê şibandin û helal tê qebûlkirin. Şerab, zikra xwedê ye û meyxane jî dergah û tekkeya sofìyan e.

\section{a- Şerab û ronahî}

Aqtepî behsa hesreta dîtina dîlberê dike û dixwaze wê bibîne, lê jê dûr e. Meraq dike ku dîlber gelo dîsa were meclîsê an na. Lê zane ku dîlber ewqas xweşik e 
ku ger mirov wê bibînin ê jixwe derbas bin. Dibêje ku eger dîlber bi naz û tac û gewheran were meclîsê dê aşiq heyîrî û matmayî bin. Destên wan ji ber şaşmayînê dê li ber devê wan be û aqil di serê wan da nemîne. Hemû ê bi ronahîya şerabê xwe wenda kin. Li vir şerab wek "ava engûr" yanî ava tirî derbas dibe. Ji ber ku şerab bi ava tirî çêdibe. Çawa ku şerab bi dîmena xwe ya sor wek roj û agir e û ronahîyê dide dora xwe, lêv jî wek şerabê dora xwe ronî dike û herkesî matmayî dike (Tarlan, 1998: 1985: 79, 273; Tolasa, 2001: 491):

Hemî medhûşî bin kef ber dihen bê 'aql $\hat{u}$ hiş yekser

Bi cunbuş têk dibin ez şewqa abê engûrî 24/24

\section{b- Cewhera șerabê}

Helbestvan tirî wek cewhera şerabê bi lêv dike. Cewher jî tê du wateyan: maddeya eslî ya tiştekî û kevirên biha û biqîmet (Kurnaz, 2009: 113; Enwerî, 1383: 397). Wek ku me got şerab ji tirî çêdibe. Bi ber vê bi wateya yekê, bingeh û cewhera şerabê tirî ye. Eger bi wateya duyem bifikirin wê demê jî wek xala jor bi alîyê ronîkirinê va û biriqînê va hatiye behskirin.

Xêncî wê Aqtepî dema behsa taybetîyên xweşîkîya yarê dike navê nergîza mexmûr tîne zimên. Nêrgîz ji bo çavên yarê tê bikaranîn. Taybetîya çavên xweşik jî mexmûrî yanî serxweşî ye. Yanî çavên yarê bi mestîyê xweşir xuya dikin. Atepî di navbera şeraba ku ji tirî hatiye çêkirin û nêrgîzê da têkilîya tenasubê jî çêkiriye:

\section{Temenna nêrgiza mexmûr, şeraba cewhera engûr}

Dil û canê me kir rencûr, kirim yexsîrê sewdaê 26/19

\section{Encam}

Şêx Ebdurrehman Aqtepî di dîwana xwe da xencî helbestên li ser mijarên dînî û terîqetî bi piranî di helbestên xwe da li ser evînê sekinîye. Di mijara evînê da jî li ser xweşîkîya yara xwe, berhevdana yara xwe û yarên din û dûrbûna ji yara xwe sekiniye. Mebesta wî ji evînê an yarê her çi be bila bibe, wî bi awayekî serkeftî helbestên xwe honandine.

Aqtepî di helbestên xwe da li ser şopa helbesta Kurdî ya klasîk çûye. Wî jî wek Melayê Cizîrî, Ehmedê Xanî an Feqîyê Teyran ji bo ku xebateke xweş derxe holê mijara evînê ji xwe ra kiriye bingeh û ji bo vê mijarê serî li gelek rêbazên edebî daye. Ji van rêbazan yek jî bikaranîna mezmûnan e. Çawa ku helbestvanên klasîk mezmûnên cur bi cur bikar anîne Aqtepî jî bi heman awayî ji gelek mezmûnan îstîfade kiriye. Beşek ji van jî mezmûnên gîyayî ne ku di dîwana Aqtepî da jî zêde cih digirin. Mezmûnên gîyayî çawa ku di wêjeya klasîk da zêdetir ji bo yarê û carinan ji bo evîndêr hatine bikaranîn Aqtepî jî ev mezmûn bi heman awayî bikar anîne. Carinan ji alîyê şeklî va, carinan jî ji alîyê rewşî va 
cih daye van mezmûnan. Ji van mezmûnên gîyayî cureyê daran bi piranî ji bo bejna yarê, cureyê kulîlkan jî ji bo xweşikîya yarê hatine bikaranîn. Beşa kulîlkan ji daran zêdetir di dîwanê da cih digirin. Lê Aqtepî dema ev mezmûn bikar anîne bi wesifandina xwezayê malikên xwe xemilandine. Bi vî awayî di hişê xwendevan da dîmenekê çêdike. Ev dîmen jî bi piranî ya demsala biharê ye ya jî baxçe ye. Ev jî têkilîya xweza û Aqtepî ya di jîyana rast da jî nîşan dide.

Aqtepî bi xebitandina van mezmûnan û van wesifandinan asta helbestên xwe bilindtir kiriye û ji bo wêjeya Kurdî berehemeke binirx li pey xwe hîştiye. Me jî bi vê xebatê hewl da ku bi mînakan bikaranîna van mezmûnan û bi vî awayî alîyê edebî yê Aqtepî nîşan bidin.

\section{Kaynakça}

'Abbûd, M. S. (2012). Lehcetu Kabîleti Kinâne Dirâsetun Luğaviyye. Mecelletu'l-Ustâz, Câmi'atu Bağdâd. 203, Bağdat, 159-182.

Acat, Y. (2018). Anadolu'da Konuşulan Arap Diyalektleri Üzerine Avrupa ve Türkiye'de Yapılan Çalışmalar. Turkish Studies, 13 (5), 29-44.

Bergstrasser, G. (2006). Sami Dilleri Tarihi, H. Kılıç ve E. Tanrıverdi (Çev.). İstanbul: Anka Yayınları.

el-Cubûrî, A. (2002). Tatavvuru'd-Dilâlâti'l-Mu'cemiyye, Bağdat: Matb ‘atu'lMecma'i'l-'İlmî'l-'Irâkî.

el-Curcânî, A. (1978). Delâilu'l-İ‘câz, Muhammed R. (tahk.), Beyrut: Dâru’lMa'rife.

Çelebi, A. İ. (1970) el-İmâletu fi'l-Kırââti ve'l-Lehecâti'l-‘Arabiyye. (2.baskı).

Kahire: Dâru Nahdati Mısr.

ed-Dâmin, H. S. (1990). Fikhu'l-Luğa, Musul: Matba'atu Dâri'l-Hikme.

---------. (1989). 'İlmu'l-Luğa, Bağdat: Matâbi‘u’t-Ta'lîmi’l‘Âlî.

Enîs, İ. (1965). Fi'l-Lehecâti'l-'Arabiyye, (2.bask1). Kahire: Mektebetu’lAngelo Misriyye.

el-Ezherî, Hâlid b. 'Abdillâh (tsz.). Şerhu’t-Tasrîh 'ale’t-Tavdîh, Beyrut: Dâr İhyâu't-Turâsi'l-'Arabî.

el-Ferâhîdî, Ebû 'Abdirrahmân el-Halîl b. Ahmed. (1980). Kitâbu'l-‘Ayn.

Mehdî M. ve İbrahim S. (tahk.). Kuveyt: Matâbi‘u’r-Risâle.

el-Feyrûzâbâdi, Mecduddîn Muhammed b. Ya'kûb. (tsz.). el-Kâmûsu'l-Muhît,

Beyrut: el-Mu'essesetu'l-'Arabiyye li't-Tibâ'a.

el-Hamevî, Şihâbuddîn Yâkût b. 'Abdillâh, (1995). Mu'cemu'l-Buldân. (2. bask1). Beyrut: Dâr Sâdır.

el-Hâşimî, A. (1960). Cevâhiru'l-Belâğa. Kahire: el-Mektebetu't-Ticâriyye.

İbn 'Abdirabbih, Ahmed b. Muhammed el-Endelusî. (1983). el-'İkdu'l-Ferîd,

Beyrut: Dâru'l-Kutubi'l-'İlmiyye.

İbn Cinnî, Ebu'l-Feth 'Usmân. (1952). el-Hasâis, Muhammed Ali en-Neccâr

(tahk.). Beyrut: Dâru'l-Kitâbi'l-'Arabî.

---------, Sirru Sinâ‘ati'l-İ'râb (1954). Mustafa es-Sakâ vd. (tahk.). Kahire: Matba'atu'l-Bâbî el-Halebî. 
İbn Hişâm, Ebû Muhammed Cemâlüddîn Abdülmelik b. Hişâm b. Eyyûb. (1978). Evdahu'l-Mesâlik ilâ Elfiyyeti İbn Mâlik. Muhammed Muhyiddîn M. A. (tahk.). Kahire: el-Mektebetu't-Ticâriyyetu'l-Kubrâ.

İbn Manzûr, Ebu'l-Fazl Cemâluddin Muhammed b. Mükerrem b. Ali. (2009) Lisânu'l-'Arab. Yâsir S. ve Mecdî F. (tahk.). Kahire: Dâru't-Tevfîkiyyeti li’tTurâs.

İbn Seyda, Ebu'l-Hasan Ali b. İsmail el-Endelusî. (1978). el-Muhassas, Beyrut: Dâru'l-Fikr.

İbnu’s-Sıkkît, Ebû Yusuf Ya‘kûb. (1978) el-İbdâl. Huseyn M. Ş. (tahk.). Kahire: el-Heyetu'l-‘Âmmetu li Şuûni'l-Matâbi'i'l-Emîriyye.

İsmail, H. ve 'Usmân, A. (2004). el-Muhallamiyya, Yayın yeri yok: Daru'lMellah.

el-Kalkaşendî, Ebu'l-'Abbâs Ahmed b. Ali. (1982). Kalâidu'l-Cumân fi't-Ta'rîfi

bi Kabâili ‘Arabi’z-Zamân. (2.baskı). İbrâhîm el-İbyârî (tahk.). Beyrut: Dâru'l-Kitâbi'l-Lubnânî.

el-Kazvînî, Ebu'l-Huseyn Ahmed b. Fâris. (1910). es-Sâhibî fî̀ Fikhi'l-Luğa. Kahire: Matba'atu'l-Mueyyid.

el-Makdisî, Ebû Abdullah b. Ahmed. (tsz.). Ahsenu't-Takâsîm fî̀ Ma'rifeti'lAkâlîm. (2.baskı). Kahire: Mektebetu Madbûlî.

el-Meşhedânî, H. A. (2010 a). Dirâsâtun Luğaviyyetun ve Nahviyye, Dimaşk: Dâru Sa'deddîn.

. (2010 b). el-Usûlu'l-Fushâ li Elfâzi'l-Lehecâti'd-Dârice. Dimaşk:

Dâr Sa'deddîn.

en-Nâdirî, M. E. (2008). Fikhu'l-Luğati Menâhiluhu ve Mesâiluh. Beyrut: elMektebetu'l-'Asriyye.

en-Nu'aymî, H. S. (1989). Asvâtu'l-‘Arabiyyeti Beyne’t-Tahavvuli ve’s-Sebât.

Musul: Matba'tu Dâri'l-Hikme.

(1980). ed-Dirâsâtu'l-Leheciyyetu ve’s-Savtiyye 'inde İbn Cinnî.

Beyrut: Dâru't-Talî‘a.

Sasse, H. J. (1971). Linguistische Analyse des Arabischen Dialekts der Mhallamiye in der Provinz Mardin. Berlin: Yayınevi yok.

es-Se‘âlîbî, Ebû Mansûr Abdilmelik b. Muhammed. (tsz.). Fikhu'l-Luğa ve Esrâru'l-‘Arabiyye. Beyrut: Dâru'l-Kutubi'l-'İlmiyye.

Sîbeveyhi, Ebû Bişr b. 'Amr b. Osman b. Kamber. (1975). el-Kitâb. Abdusselam H. (tahk.). Beyrut: 'Âlemu'l-Kutub.

es-Suyûtî, Celâluddîn Ebû Bekr b. Abdirrahman. (2010). el-Muzhir fî Ulûmi'lLuğati ve Envâ'ihâ. eş-Şirbînî Ş. (tahk.). Kahire: Dâru'l-Hadîs.

Şahin, A. (1966). el-Kırââtu'l-Kur'âniyye fî Dav'i 'İlmi'l-Luğati'l-Hadîs. Kahire: Mektebetu'l-Hâncî.

Şîr, A. (2007). Târîhu Kaldû ve Âşûr. Yayın yeri yok: Mektebu Serkîs Ağacan. 
et-Ta“'ân, H. (1968). Teesurul'l-'Arabiyyeti bi'l-Luğâti'l-Yemeniyyeti'lKadîme. Bağdat: Matba'atu'l-İrşâd.

Vâfî, A. A. (1945). el-Luğatu ve'l-Mucteme‘. Yayın yeri yok: Matba'atu'lBâbi'l-Halebî.

'Umar, A. M. (1976). Dirâsetu’s-Savti’l-Luğavî. Kahire: ‘Âlemu’l-Kutub.

'Usmân, A. (2011). el-Lehcetu'l-‘Arabiyyetu'l-Muhallemiyye Beyne'l-Fasîhi ve'l-'Âmmiyyi ve'd-Dahîl. Dimaşk: Matba'atu'l-Yemâme.

Vardar, B. (2002). Açıklamalı Dilbilim Terimleri Sözlüğü. İstanbul: Multilingual Yayınları.

el-Vâsitî, Ebû Muhammed Abdillâh. (2004). el-Kenzu fi'l-Kırââti'l-'Aşr. Hâlid A. M. (tahk.). Kahire: Dâru'l-Misrî li't-Tibâ'a.

ez-Zebîdî, Muhammed b. Muhammed b. Abdurrezzak. (tsz.). Tâcu'l-'Arûs min Cevâhiri'l-Kâmûs. (2.baskı). Kuveyt: Dâru'l-Hidâye. 